\title{
Situation of and phenotypic markers of susceptibility to helminth infection among sheep on farms in the Brazilian cerrado biome
}

\author{
Diagnóstico de situação e marcadores fenotípicos das parasitoses gastrintestinais \\ em ovinos de fazendas localizadas no Distrito Federal: bioma cerrado brasileiro \\ Roberta Tavares Moreira1* (1); Ana Lourdes Arrais de Alencar Mota² (D); Vitor Salvador Picão Gonçalves² (D); \\ Gino Chaves da Rocha ${ }^{3}$ (D); José Renato Junqueira Borges ${ }^{4}$ (D) \\ ${ }^{1}$ Instituto Federal de Brasília - IFB, Brasília, DF, Brasil \\ ${ }^{2}$ Departamento de Epidemiologia e Planejamento em Saúde Animal, Faculdade de Agronomia e Medicina Veterinária, Universidade de \\ Brasília - UnB, Brasília, DF, Brasil \\ ${ }^{3}$ Laboratório de Parasitologia e Doenças Parasitárias, Faculdade de Agronomia e Medicina Veterinária, Universidade de Brasília - UnB, \\ Brasília, DF, Brasil \\ ${ }^{4}$ Hospital de Grandes Animais, Faculdade de Agronomia e Medicina Veterinária, Universidade de Brasília - UnB, Brasília, DF, Brasil
}

How to cite: Moreira RT, Mota ALAA, Gonçalves VSP, Rocha GC, Borges JRJ. Situation of and phenotypic markers of susceptibility to helminth infection among sheep on farms in the Brazilian cerrado biome. Braz J Vet Parasitol 2021; 30(1): e021720. https:// doi.org/10.1590/S1984-296120201092

\begin{abstract}
This study aimed to determine the intensity, seasonality, and distribution by genera of, as well as to identify phenotypic markers of susceptibility to, gastrointestinal parasites among sheep on farms within the Brazilian savanna (cerrado) biome. We evaluated 1271 sheep, on seven farms, during the rainy season (in December 2017 and December 2018) and dry season (in July 2018 and July 2019). Parasitological evaluation was based on culture and EPG. We calculated hematocrit, as well as the body condition score and feces score. Of the sheep evaluated, $34.15 \%$ had moderate-to-severe parasitic infection. The factors of herds' phenotypic characterization about helminth infections were $(p \leq 0.05$ for all): anemia $(O R=5.72)$; leanness $(O R=1.80)$; loose stools or diarrhea $(O R=1.54)$; breed other than Santa Inês $(O R=2.31)$; "weaned lamb" category $(O R=4.76)$; "lambing ewe" category $(\mathrm{OR}=4.66)$; and dry season ( $\mathrm{OR}=2.37)$. Haemonchus, Trichostrongylus, Oesophagostomum, and Cooperia accounted for $76.40 \%, 20.23 \%, 2.89 \%$, and $0.47 \%$, respectively, of the helminth genera identified, with their proportional distributions being comparable between the rainy and dry seasons. Changes in health management, with regard to helminth infection control, are urgently needed in order to combat the disease more effectively and sustainably.
\end{abstract}

Keywords: Sheep farming, helminth infection, epidemiology, phenotypic markers, Brazilian cerrado.

\begin{abstract}
Resumo
A presente pesquisa objetivou determinar a intensidade, sazonalidade, predominância de gêneros e marcadores fenotípicos às parasitoses gastrointestinais em fazendas de criação de ovinos do Distrito Federal, no bioma cerrado brasileiro. Foram avaliados 1.271 ovinos oriundos de sete propriedades, durante os períodos chuvoso (dezembro de 2017 e dezembro de 2018) e seco (julho de 2018 e julho de 2019). Procedeu-se a avaliação parasitológica por coprocultura e OPG, dosagem de hematócrito, escore de condição corporal e de fezes. Dos indivíduos avaliados, 34,15\% deles apresentaram infecção parasitária moderada a grave. Os fatores de caracterização fenotípica dos rebanhos quanto às infecções helmínticas ( $p \leq 0,05)$ foram: anemia $(O R=5,72)$, magreza $(O R=1,80)$, fezes pastosas/diarreicas $(O R=1,54)$, raças distintas à raça Santa Inês $(O R=2,31)$, categorias de produção animal "jovens" $(O R=4,76)$ e "fêmeas paridas" $(\mathrm{OR}=4,66)$, e período seco (OR = 2,37). Haemonchus, Trichostrongylus, Oesophagostomum e Cooperia foram os gêneros de helmintos observados nas seguintes proporções: 76,40\%, 20,23\%, 2,89\% e 0,47\%, respectivamente, sem distinção em sua distribuição entre os períodos chuvoso e seco. Mudanças no manejo sanitário com relação às helmintoses são urgentemente necessárias, para um controle da doença de forma mais eficaz e sustentável.
\end{abstract}

Palavras-chave: Criação de ovinos, infecção helmíntica, epidemiologia, marcadores fenotípicos, cerrado brasileiro.

Received September 7, 2020. Accepted December 9, 2020.

*Corresponding author: Roberta Tavares Moreira. E-mail: roberta.moreira@ifb.edu.br

This is an Open Access article distributed under the terms of the Creative Commons Attribution License, which permits unrestricted use distribution, and reproduction in any medium, provided the original work is properly cited. 


\section{Introduction}

Sheep farming is a major animal production system with significant expansion worldwide. From 2011 to 2016, the global sheep industry showed an annual growth rate of 1.5\%, with an estimated flock of 1.17 billion head in 2016 (EMBRAPA, 2019; Martins et al., 2016). Brazil ranks 18th among the main sheep-producing countries worldwide (EMBRAPA, 2019), with 18.94 million head (IBGE, 2018), and occupies a prominent position in the Americas, where it is the largest producer and the second largest consumer (Sorio et al., 2016).

One of the major hindrances to the productive potential of sheep farming is infection with gastrointestinal parasites, which is a major health problem for the species, especially in countries with tropical climates (FAO, 1998). In Brazil, infection with intestinal worms is the leading cause of ill-health and production losses in sheep farming systems (Carneiro \& Amarante, 2008; Igarashi et al., 2013; Ramos et al., 2002).

In the northeastern and southern regions of Brazil, which have the first and second largest sheep flocks, respectively (IBGE, 2018), gastrointestinal parasites have been a major topic of study. However, in the central-west region, which has the third largest flock and very different bioclimatic conditions, the scenario of gastrointestinal parasites in sheep is still practically unknown. The absence of epidemiological data regarding gastrointestinal parasites in sheep production systems in the Federal District of Brazil, where the predominant biome is savanna (cerrado in Portuguese) and there are typically two climatic periods: a rainy season (October to April), with average monthly precipitation of 202 millimeter (according to the historical series of the last 30 years), greater cloud cover, elevated temperatures, and low thermal amplitude; and a dry season (May to September), with average monthly precipitation of 25.6 millimeter (according to the historical series of the last 30 years, too), low relative humidity, high solar radiation, and high thermal amplitude (Barros, 2003; Climatempo, 2020).

The aim of this study was to determine the intensity and seasonality of infection with gastrointestinal parasites on sheep farms in the Brazilian cerrado biome. We also evaluated the proportional distribution of nematode genera and the relationships among phenotypic markers of characterization in sheep herds about susceptibility to gastrointestinal parasites.

\section{Material and Methods}

This study was approved by the Ethics Committee on Animal Use of the University of Brasília (Reference no. 70/2017).

Farms, animals, collection periods, and sample design

We evaluated 1271 sheep, with a total of 1435 observations, on seven farms located in the Federal District of Brazil, where the biome is typical Brazilian cerrado. All of the farms employed semi-intensive breeding systems, with breeds and racial crossbreeding dedicated to meat production. Sheep, in each production category, were evaluated in the rainy season-in December 2017 (472 observations) and December 2018 (321 observations)-and in the dry season-in July 2018 (381 observations) and July 2019 (261 observations).

Of the 1435 observations made throughout the 4 evaluations periods, 328 were derived from 164 individuals that were sampled twice (at two separate time points). After the mean number helminth eggs per gram (EPG) had been obtained, a paired t-test showed significant differences between the two time points $(p<0.001)$. Given the results of the statistical analysis applied, the biological conditions, the fact that the animals migrate between the different categories during their life, and that present paper is a longitudinal evaluation of local field sheep raising conditions, repetitions were not disregarded and were thus maintained in the analysis as new observations, resulting in a total of 1435 samples.

Regarding the number of animals to be evaluated, the minimum sample size has been defined as that corresponding to $10 \%$ of the total number of sheep in each production category (Hassum, 2008): lactating lambing ewe (adult non-pregnant lactating ewe); pregnant ewe (adult ewe at any stage of pregnancy); solitary ewe (adult nonpregnant, non-lactating ewe); ram (adult male with full reproductive capacity); and weaned lamb (non-suckling male or female sheep between 2 and 8 months of age). Therefore, on each farm, we performed sampling by production category, in which a systematic random process was used in order to select the animals. 


\section{Parasitological and clinical evaluation}

The target animals were submitted to clinical and parasitological evaluation in each of the four above mentioned periods. None of the flocks were submitted to deworming during the 60 days preceding the field collections. In the parasitological evaluation, the feces were collected into plastic bags, directly from the rectal ampulla of each individual, and stored in refrigerated polystyrene containers, properly identified, for subsequent counting of the number of helminth eggs per gram (EPG), with the method devised by Gordon \& Whitlock (Chagas et al., 2011; Ueno \& Gonçalves, 1998), and culture via the Roberts and O'Sullivan technique (Ueno \& Gonçalves, 1998), with morphometric and morphological classification of third-stage (infective) larvae according to the identification keys devised by Ueno \& Gonçalves (1998) and by Van Wyk et al. (2004). In the EPG analysis, we observed several types of eggs, such as those of the class Cestodes (Moniezia spp.) and of Strongyloides spp., as well as oocysts of Eimeria spp. However, for the statistical analyses, we quantified only eggs of the order Strongylida.

During each of the evaluation periods, fecal samples were collected in the morning. Within 24 hours after collection, each sample underwent fecal examination, and the results were grouped by production category (lactating lambing ewes, pregnant ewes, solitary ewes, rams, and weaned lambs). The cultures were processed from a pool of samples, by production category, from each farm evaluated in each collection period. The feces were classified as normal (with well-defined borders and in a form typical of the species), loose (a single, amorphous mass), or diarrheic (fluid and amorphous).

On the same day as the collection of feces, the animals underwent clinical hematological evaluation, together with determination of the body condition score (BCS) devised by Thompson \& Meyer (1994). Blood samples were collected, by venipuncture of the external jugular, into tubes containing ethylenediaminetetraacetic acid anticoagulant (Vacutainer; Becton Dickson, Oxford, England), for laboratory hematocrit tests, as described by Lopes et al. (2007). At each of the farms, a questionnaire was applied in order to determine the general and health management practices, regarding the control of parasites, adopted in the production systems in question.

\section{Statistical analysis}

The following variables were considered for analysis: collection period (December 2017, July 2018, December 2018, and July 2019), farm, breed of sheep, production category (pregnant ewe, solitary ewe, lactating lambing ewe, ram, and weaned lamb), BCS (1-5), hematocrit, stool characteristic (normal, loose or diarrheic), and parasitic infection (mild vs. moderate/severe), the last being the dependent variable for comparison in univariate and multivariate analyses, in which mild parasitic infection was defined as a Strongylida EPG $<800$ and moderate-tosevere parasitic infection was defined as a Strongylida EPG $\geq 800$ (Hansen \& Perry, 1994).

For the applied statistical analyses, the individual weights of all animals were considered, according to the Formula 1 below:

Individual weight $=N_{\text {total }} / n_{\text {collected }}$

where $N_{\text {total }}$ is the total number of individuals in the production category, on each farm in each period, and $n_{\text {collected }}$ is the number of target animals evaluated, on each farm in each period (representativeness of each individual to their sample population, in each category of ownership and production).

Descriptive statistics were calculated as mean, standard deviation, and percentile, or as absolute and relative frequencies, with $95 \%$ confidence intervals. When necessary, some of the quantitative variables were categorized and some of the qualitative variables were re-categorized. The grouping of observations into categories was based on the statistical behavior of the variables, as well as on their biological principles (physiological aspects and clinical behavior of the animal). Thus, the variables were paired as follows: EPG $<800$ (mild parasitic infection) versus EPG $\geq 800$ (moderate-to-severe parasitic infection) (Hansen \& Perry, 1994); hematocrit $<24 \%$ (anemia) versus $\geq 24 \%$ (Viana, 2014); lean body (BCS of 1 or 2) versus BCS normal-to-fat body (BCS of 3, 4, or 5); Santa Inês versus other breeds; normal feces versus loose/diarrheic feces; and rainy season versus dry season. We also drew comparisons among the production categories.

The variables were submitted to univariate analysis of the data, with the chi-square test and Fisher's exact test. Those that presented a value of $p \leq 0.20$ were selected for inclusion in the multiple logistic regression model in a design-based format, with hierarchical backward elimination. In that format, the weight of each sampled animal in the five sampling production categories and on each of the seven farms was considered, which is more 
appropriate for population inference of the magnitude of the risk factors. Variables presenting a value of $p \leq 0.05$ were considered statistically significant. The lowest risk categories were taken as the baseline for comparison with the others. The farm was considered the control variable in the applied multiple logistic regression model, given the correlation between animals on the same farms. All calculations, and the vertical box plot graphics, were performed with Stata software, version 12.0 (Statacorp, 2011).

\section{Results}

Among the farms evaluated, the average size was 170 ha (range, 20-400 ha), the average pasture area was 53.8 ha (19.5-200 ha), and the average stocking rate was 7.4 head of sheep/ha. The properties had been used for sheep farming for an average of 11.6 years (range, 2-20 years). Sheep farming was the main source of income for the production system on only $28.6 \%$ of the farms. That reflects the fact that $100 \%$ of the farms evaluated had adopted another production system concomitant to sheep farming (85.7\% raised cattle, $57.1 \%$ raised horses, $42.8 \%$ raised goats, $28.6 \%$ raised pigs, and $14.3 \%$ raised birds or fish). On $71.4 \%$ of the farms, pasture area was shared between sheep and other species, such as cattle and horses. Pasture rotation was adopted on $57.1 \%$ of the farms. The forage grasses most widely used as sources of roughage in the pastures of the farms evaluated were Panicum spp., Brachiaria spp., and Cynodon spp.

Anthelmintic treatment was used as regular management in all flocks, on a quarterly basis (on $42.8 \%$ of the farms), an annual basis (on 28.6\% of the farms), or as necessary (Abrão et al., 2010; Amarante et al., 2015), according to parasitological results and clinical symptoms (on $28.6 \%$ of the farms). On $71.4 \%$ of the farms, deworming was carried out en masse. On $85.7 \%$ of the farms evaluated, the weight of each animal (on which the dose of anthelmintic was based) was determined by visual appraisal. The anthelmintics most often used on the farms evaluated were macrocyclic lactones, imidazothiazoles, and benzimidazoles. An efficacy test was not adopted as a criterion for choosing anthelmintic drugs on any of the farms evaluated. Rather, the drugs were selected on the recommendation of professionals working in the region (technicians who provide services to the farms, agricultural store attendants, or commercial representatives), from advertisements, or on the basis of economic criteria. On $71.4 \%$ of the farms, a different anthelmintic drug was used every year. An equal proportion of farms did not use the EPG or the FAMACHA eyelid color test (Van Wyk \& Bath, 2002; Vatta et al., 2001) as a parasitological and clinical evaluation to indicate the need for anthelmintic treatment.

During the first evaluation period (December 2017), the average precipitation was $246 \mathrm{~mm}$, the average maximum temperature was $26.5^{\circ} \mathrm{C}$, the average minimum temperature was $18.5^{\circ} \mathrm{C}$, and the average relative humidity was $75 \%$ (INMET, 2017). During the second evaluation period (July 2018), there was no precipitation (the last recorded rainfall having been $3 \mathrm{~mm}$ on May 20,2018, 52 days prior to the first sample collection in the period), the average maximum temperature was $26.0^{\circ} \mathrm{C}$, the average minimum temperature was $11.0^{\circ} \mathrm{C}$, and the average relative humidity was $52 \%$ (INMET, 2018). During the third evaluation period (December 2018), the average precipitation was $250 \mathrm{~mm}$, the average maximum temperature was $28.0^{\circ} \mathrm{C}$, the average minimum temperature was $17.0^{\circ} \mathrm{C}$, and the average relative humidity was $80 \%$ (CPTEC, 2019). During the fourth and final evaluation period (July 2019), there was no precipitation (the last recorded rainfall having been $8 \mathrm{~mm}$ on June 3, 2019, 37 days prior to the first sample collection in the period), the average maximum temperature was $24.5^{\circ} \mathrm{C}$, the average minimum temperature was $13.0^{\circ} \mathrm{C}$, and the average relative humidity was $54 \%$ (INMET, 2019).

We observed the following mean Strongylida EPG values in the four evaluation periods: $844.5 \pm 1,719.6$ (in December 2017); 1,401.9 $\pm 2,237.3$ (in July 2018); 1,146.4 $\pm 2,682.6$ (in December 2018); and 1,357.5 $\pm 3,366.8$ (in July 2019). As can be seen in Table 1, there was a tendency toward higher mean values of EPG and higher proportions of individuals with high parasite loads during the dry season (July 2018 and July 2019). When the sheep were stratified by EPG (Hansen \& Perry, 1994), we found that the percentiles at which the cutoff of an EPG $\geq 800$ (indicating moderate-to-severe infection) was reached were 76.0, 51.6, 71.5 and 63.0, in the four evaluation periods, respectively, showing the tendency toward higher proportions of animals with moderate-to-severe infection in the dry season.

Infective larvae (L3) of the genera Haemonchus, Trichostrongylus, Oesophagostomum, and Cooperia were identified of cultures in all four evaluation periods, with similar proportional distributions during the dry and rainy seasons (Figure 1). In the cultures performed in all four periods, as well as in the rainy and dry season, the predominant genus identified was Haemonchus $(76.40 \%$ in total culture; $74.85 \%$ and $95 \% \mathrm{Cl} 68.57 \%$ to $81.13 \%$ in rainy season; $77.95 \%$ and $95 \% \mathrm{Cl} 73.33 \%$ to $82.56 \%$ in dry season), followed by the Trichostrongylus (20.23\% in total culture; $22.43 \%$ 
Table 1. Parasite load distribution (of Strongylida) of sheep in the four evaluation periods, by percentile, in the Brazilian cerrado.

\begin{tabular}{|c|c|c|c|c|}
\hline \multirow{2}{*}{ Percentile } & \multicolumn{4}{|c|}{ EPG } \\
\hline & December 2017 & July 2018 & December 2018 & July 2019 \\
\hline $1 \mathrm{st}$ & 0 & 0 & 0 & 0 \\
\hline 5 th & 0 & 0 & 0 & 0 \\
\hline 10th & 0 & 50 & 0 & 0 \\
\hline 25th & 0 & 200 & 50 & 150 \\
\hline 50th & 200 & 750 & 250 & 450 \\
\hline 75th & 750 & 1700 & 1100 & 1300 \\
\hline 90th & 2250 & 3750 & 3000 & 3000 \\
\hline 95th & 4550 & 5200 & 5050 & 5350 \\
\hline 99th & 8800 & 8300 & 13000 & 11450 \\
\hline
\end{tabular}

EPG: eggs per gram.

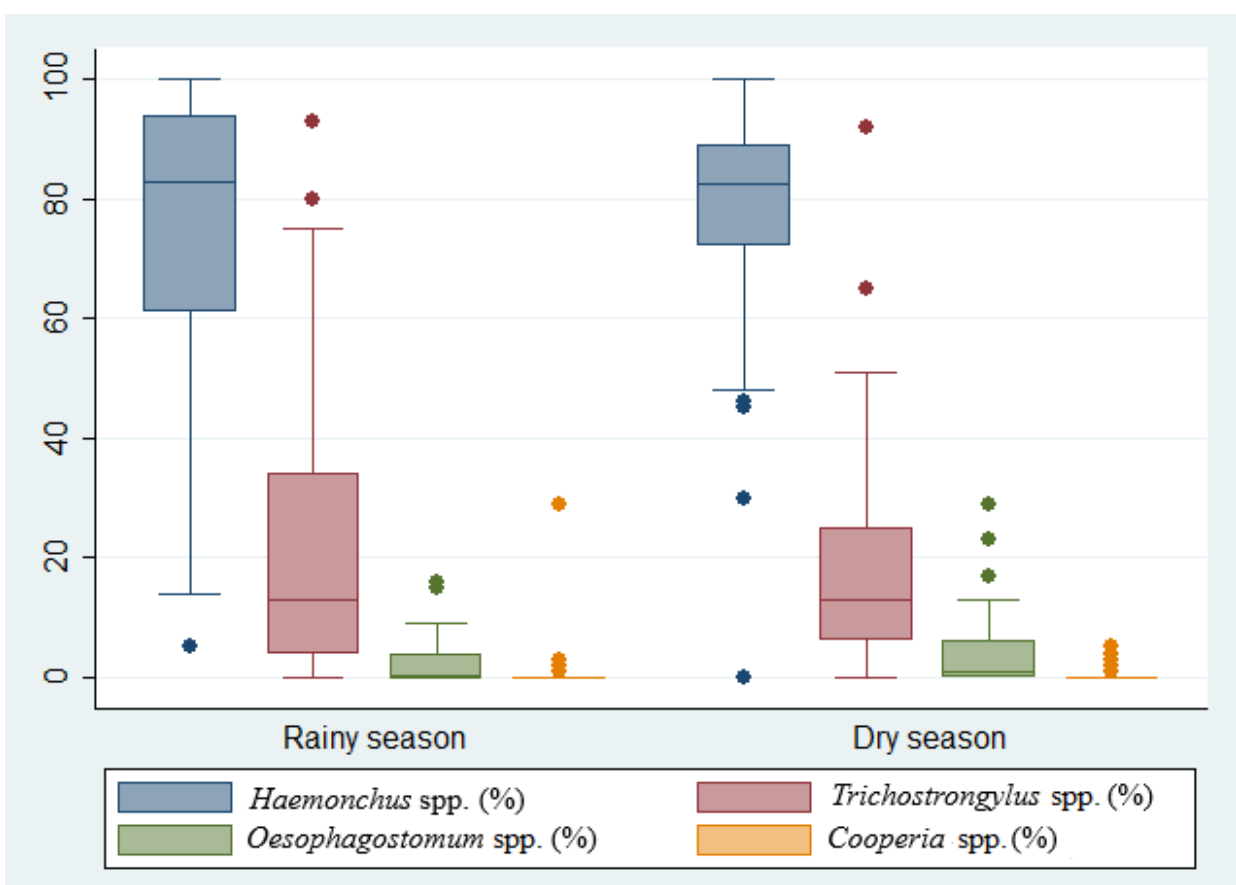

Figure 1. Proportional distribution of helminth genera, by season, of sheep in the Brazilian cerrado.

and $95 \% \mathrm{Cl} 16.52 \%$ to $28.35 \%$ in rainy season; $18.03 \%$ and $95 \% \mathrm{Cl} 13.64 \%$ to $22.41 \%$ in dry season). Among the production categories evaluated, Haemonchus was also the predominant helminth genus, accounting for $69.64 \%$ to $84.35 \%$ of the genera identified in the various production categories (Figure 2).

Only $10 \%$ of the animals evaluated presented anemia (hematocrit $<24 \%$ ). Overall, the mean value of hematocrit was $30.84 \pm 5.51 \%$. The mean hematocrit, by evaluation period, was $31.38 \pm 5.49 \%$ in December $2017 ; 29.37 \pm$ $5.57 \%$ in July 2018; $31.94 \pm 5.07 \%$ in December 2018; and $30.67 \pm 5.54 \%$ in July 2019 . Among the four evaluation periods, higher proportions of anemic animals occurred in the dry season (18\% and $12 \%$ of anemic animals in July 2018 and July 2019, respectively), compared to the rainy season (8\% and 6.5\% in December 2017 and December 2018, respectively).

Of the 1435 sheep evaluated over the two-year study period, 490 (34.15\%) had EPG values $\geq 800$. The highest proportions of animals with a low parasite load (EPG < 800) were observed in December 2017 and December 2018. The proportion of animals with moderate-to-severe helminth infection was highest in the dry season $(p<0.05)$ (Table 2). 


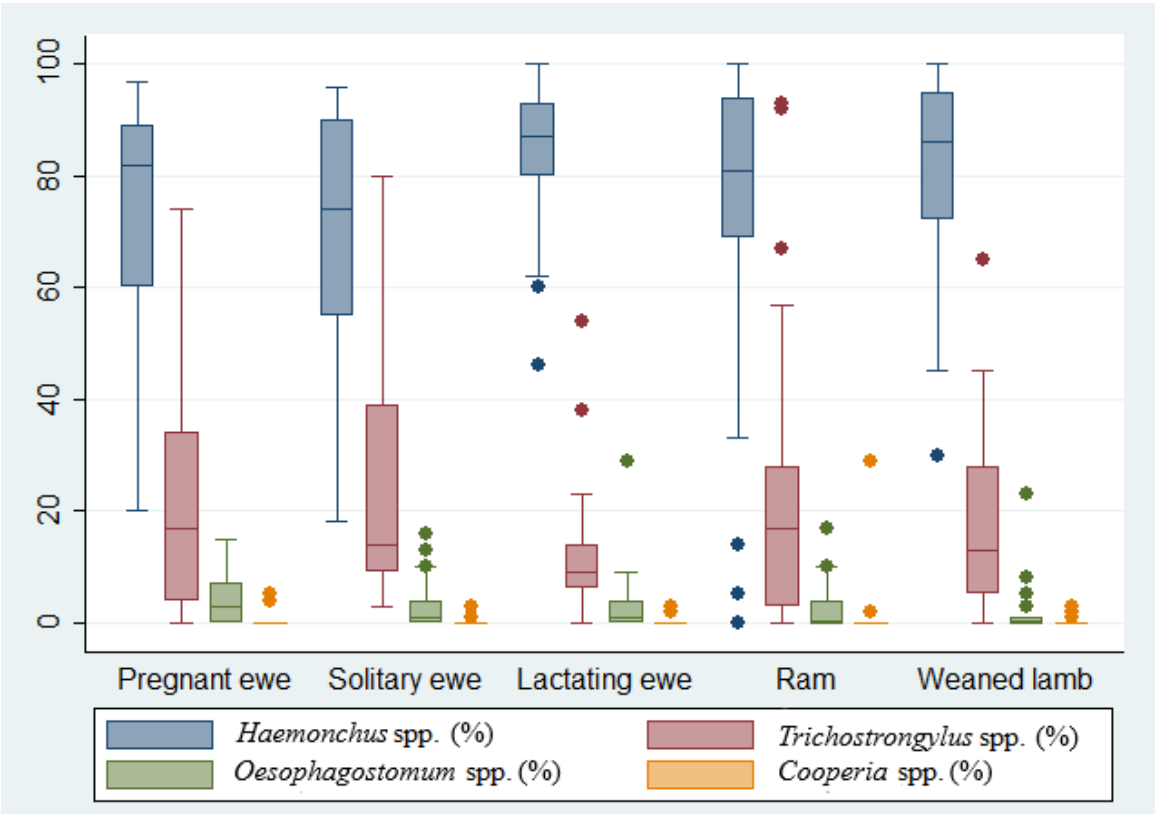

Figure 2. Proportional distribution of helminth genera, by production category, of sheep in the Brazilian cerrado.

Table 2. Distribution of sheep with mild and moderate-to-severe parasitic infection, in the rainy and dry evaluation periods, in the Brazilian cerrado.

\begin{tabular}{|c|c|c|c|}
\hline EPG & Proportion & \multirow{2}{*}{ SD } & \multirow{2}{*}{$95 \% \mathrm{Cl}$} \\
\hline Season & $(\%)$ & & \\
\hline \multicolumn{4}{|l|}{$<800$} \\
\hline Rainy & 74.99 & 1.79 & $71.48 ; 78.50$ \\
\hline Dry & 56.33 & 2.25 & $51.92 ; 60.75$ \\
\hline \multicolumn{4}{|l|}{$\geq 800$} \\
\hline Rainy & 25.01 & 1.79 & $21.50 ; 28.52$ \\
\hline Dry & 43.67 & 2.25 & $39.25 ; 48.07$ \\
\hline
\end{tabular}

EPG: eggs per gram; SD: standard deviation; 95\%Cl: confidence interval in 95\%.

When re-categorizing the BCS variable, based on the classification of animals with a BCS of 1 or 2 as lean and those with a BCS of 3,4 , or 5 as normal-to-fat, we found that there was a predominance of lean animals during the dry seasons and a predominance of normal-to-fat animals during the rainy seasons $(p<0.05)$ (Table 3$)$.

Among the breeds and crossbreeds studied (Table 4), the proportion of animals with moderate-to-severe parasitic infection (EPG $\geq 800$ ) was significantly lower among sheep of the Santa Inês breed than among those of other breeds $(p<0.05)$, also, Santa Inês and Dorper breed presented the lowest proportions of anemic animals, with $6.6 \%$ and $6.0 \%$, respectively. Among the production categories (Table 5), the proportions of animals with a high parasite load and, consequently, parasitic challenge, was highest in the lactating lambing ewe and weaned lamb categories $(p<0.05)$.

Table 6 shows the results of the univariate analysis of the phenotypic markers for intestinal parasites in sheep rearing systems under the bioclimatic conditions evaluated. The following variables achieved a value of $p \leq 0.20$ : production category, sheep breed, BCS, hematocrit, feces characteristic, and season.

In the final multiple logistic regression model for identifying phenotypic markers characteristics of a higher occurrence of moderate to severe helminth infection in sheep from Brazilian cerrado (Table 7), lactating lambing ewes and weaned lambs were found to be the groups most susceptible to intestinal parasites, with a 4.66 and 4.76 times greater odds of helminth infection, respectively, in comparison with solitary ewes $(p=0.000)$, whereas pregnant ewes were comparable to solitary ewes $(p=0.214)$. 
Table 3. Proportional distribution of lean and normal-to-fat sheep, in the four evaluation periods, in the Brazilian cerrado.

\begin{tabular}{cccc}
\hline Body condition score & Proportion & SD & 95\% Cl \\
\cline { 1 - 1 } Period & (\%) & & $21.72 ; 29.45$ \\
1 or 2 (lean) & 25.60 & 1.97 & $44.25 ; 55.30$ \\
December 2017 & 49.78 & 2.81 & $24.74 ; 36.87$ \\
July 2018 & 30.81 & 3.09 & $45.67 ; 60.22$ \\
December 2018 & 52.95 & 3.71 & $70.55 ; 78.27$ \\
July 2019 & & & $44.70 ; 55.74$ \\
December 2017 & 74.40 & 1.97 & $63.13 ; 75.25$ \\
July 2018 & 50.22 & 2.81 & $39.77 ; 54.35$ \\
\hline
\end{tabular}

SD: standard deviation; 95\%Cl: confidence interval in 95\%.

Table 4. Proportional distribution of sheep with mild and moderate-to-severe infection, by breed, in the Brazilian cerrado.

\begin{tabular}{cccc}
\hline & \multicolumn{2}{c}{ Severity of infection } & Moderate/severe \\
\cline { 2 - 3 } Sheep breed & Mild & $\mathbf{n}(\%)$ & 759 \\
\cline { 2 - 3 } Crossbreed & $486(64.03)$ & $273(35.97)$ & 365 \\
Santa Inês & $272(74.52)$ & $93(25.48)$ & 186 \\
Dorper & $113(60.75)$ & $73(39.25)$ & 70 \\
White Dorper & $49(70.00)$ & $21(30.00)$ & 35 \\
Ile de France & $13(37.14)$ & $22(62.86)$ & 20 \\
Suffolk & $12(60.00)$ & $8(40.00)$ & 1435 \\
\hline
\end{tabular}

n: number of animals with mild or moderate to severe infection; $N$ : total number of animals in the respective sheep breeds.

Table 5. Proportional distribution of sheep with mild and moderate-to-severe infection, by production category, in the Brazilian cerrado.

\begin{tabular}{|c|c|c|c|}
\hline \multirow{3}{*}{ Production category } & \multicolumn{2}{|c|}{ Severity of infection } & \multirow{3}{*}{$\mathbf{N}$} \\
\hline & Mild & Moderate/severe & \\
\hline & n (\%) & n (\%) & \\
\hline Pregnant ewe & $288(74.23)$ & $100(25.77)$ & 388 \\
\hline Solitary ewe & $297(78.57)$ & $81(21.43)$ & 378 \\
\hline Lactating lambing ewe & $101(46.33)$ & $117(53.67)$ & 218 \\
\hline Ram & $81(71.68)$ & $32(28.32)$ & 113 \\
\hline Weaned lamb & $178(52.66)$ & $160(47.34)$ & 338 \\
\hline Total & $945(65.85)$ & $490(34.15)$ & 1435 \\
\hline
\end{tabular}

$\mathrm{n}$ : number of animals with mild or moderate to severe infection; $\mathrm{N}$ : total number of animals in the respective production categories. 
Table 6. Results of univariate analyses of phenotypic markers for intestinal parasites in sheep rearing systems in the Federal District of Brasília, Brazil.

\begin{tabular}{|c|c|c|c|}
\hline \multirow{3}{*}{ Variables } & \multicolumn{2}{|c|}{ Severity of infection } & \multirow{3}{*}{$\mathbf{p}$} \\
\hline & Mild & Moderate/severe & \\
\hline & $n / N$ & $n / N$ & \\
\hline \multicolumn{4}{|l|}{ Production category } \\
\hline Pregnant ewe & $288 / 945$ & $100 / 490$ & 0.000 \\
\hline Solitary ewe & $297 / 945$ & $81 / 490$ & \\
\hline Lactating lambing ewe & $101 / 945$ & $117 / 490$ & \\
\hline Ram & $81 / 945$ & $32 / 490$ & \\
\hline Weaned lamb & $178 / 945$ & $160 / 490$ & \\
\hline \multicolumn{4}{|l|}{ Breed } \\
\hline Santa Inês & $272 / 945$ & $93 / 490$ & 0.000 \\
\hline Other & $673 / 945$ & $397 / 490$ & \\
\hline \multicolumn{4}{|l|}{ Body condition score } \\
\hline 1 or 2 (lean) & $299 / 945$ & $253 / 490$ & 0.000 \\
\hline 3-5 (normal-to-fat) & $646 / 945$ & $237 / 490$ & \\
\hline \multicolumn{4}{|l|}{ Hematocrit } \\
\hline$<24 \%$ & $33 / 945$ & $100 / 490$ & 0.000 \\
\hline$\geq 24 \%$ & $912 / 945$ & $390 / 490$ & \\
\hline \multicolumn{4}{|l|}{ Feces } \\
\hline Normal & $588 / 945$ & $283 / 490$ & 0.106 \\
\hline Loose to diarrheic & $357 / 945$ & $207 / 490$ & \\
\hline \multicolumn{4}{|l|}{ Season } \\
\hline Rainy & $585 / 945$ & $208 / 490$ & 0.000 \\
\hline Dry & $360 / 945$ & $282 / 490$ & \\
\hline
\end{tabular}

$\mathrm{n} / \mathrm{N}$ : number of animals with mild or moderate to severe infection / total number of animals with mild or moderate to severe infection. $\mathrm{p}$ : $\mathrm{p}$-value.

Table 7. Final multiple logistic regression model of phenotypic markers of susceptibility to gastrointestinal parasites in sheep farming systems in the Federal District of Brasília, within the Brazilian cerrado biome*.

\begin{tabular}{|c|c|c|c|}
\hline Variables & Odds ratio & $95 \% \mathrm{Cl}$ & $\mathbf{p}$ \\
\hline \multicolumn{4}{|l|}{ Production category } \\
\hline \multicolumn{4}{|l|}{ Solitary ewe (baseline) } \\
\hline Pregnant ewe & 1.29 & $0.86 ; 1.94$ & 0.214 \\
\hline Ram & 2.22 & $1.20 ; 4.08$ & 0.011 \\
\hline Lactating lambing ewe & 4.66 & $2.92 ; 7.43$ & 0.000 \\
\hline Weaned lamb & 4.76 & $3.07 ; 7.38$ & 0.000 \\
\hline Loose to diarrheic feces & 1.54 & $1.14 ; 2.09$ & 0.005 \\
\hline Lean body condition score & 1.80 & $1.34 ; 2.41$ & 0.000 \\
\hline Breed other than Santa Inês & 2.31 & $1.62 ; 3.29$ & 0.000 \\
\hline Dry Season & 2.37 & $1.77 ; 3.17$ & 0.000 \\
\hline Hematocrit < 24\% & 5.72 & $3.32 ; 9.83$ & 0.000 \\
\hline
\end{tabular}

*The odds ratio for the control variable (farm) was omitted; 95\%Cl: confidence interval in 95\%; p: p-value. 
Anemia was associated with a 5.72 times greater chance of presenting moderate-to-severe parasitic infection in comparison with animals with a normal hematocrit $(p=0.000)$. Animals with loose stools or diarrhea were 1.54 times more likely to have a high parasite load than were animals with normal feces $(p=0.005)$. Animals with a BCS of 1 or 2 were 1.80 times more likely to develop moderate-to-severe parasitic infection than were those with a BCS of 3,4 , or $5(p=0.000)$.

Sheep of the breeds Dorper, White Dorper, Suffolk, lle de France, well as crossbred sheep, were found to be at 2.31 times greater odds of presenting a high parasite load than were those of the Santa Inês breed $(p=0.000)$. During the dry season, animals presented 2.37 times greater odds of having a high parasite load than in the rainy season $(p=0.000)$.

\section{Discussion}

Infection with intestinal parasites is a complex phenomenon, given the numerous factors that can influence its occurrence, including the clinical conditions of flocks, such as aspects intrinsic to animals (genetics, production category, age, physical condition, etc.), and aspects dependent on the production environment, such as management, nutrition, climatic conditions, and types of forage grass (Amarante et al., 2015; Cardia et al., 2011; Carneiro \& Amarante, 2008; Costa et al., 2007; Santos et al., 2012; Veríssimo et al., 2012). Treating this phenomenon in a simplistic way, without considering the interrelationships of multiple factors, may result in failures in the interpretation and control of the disease, culminating in health and economic losses.

On a significant proportion of the sheep farms evaluated in the present study, incipient technological advances and specialization have led to the concomitant production of animals other than sheep. Failures in health management, regarding the control of worms, are also common. The deworming of flocks en masse, without the use of selective criteria for treatment, without weighing animals to determine the appropriate dosage of anthelmintic drugs, and without using criteria for choosing references, was found to be common practice, which certainly resulted in unnecessary expenditures and had a negative impact on the health of flocks, as well as promoting selection for resistant parasites.

It is logical to assume that gastrointestinal worms are more abundant during rainy periods, because of ecological conditions favoring to the persistence of viable helminth larvae in pasture lands, increasing the risk of infection of ruminants (Charles, 1995; Girão et al., 1998). In the dry period, due to the low levels of relative humidity and low temperatures, there is a considerable reduction in helminths in the free-living phase (eggs and larvae), which, despite being concentrated in parasitized animals, do not necessarily remain in loads that justify the occurrence of clinical symptoms (Costa et al., 2011; Vieira, 2008). Ever under adverse climatic conditions to the presence of helminths' eggs and larvae in pasture, and consequently, infection to the animals, we observed a trend toward higher parasite loads in sheep during the dry season. The mean EPG values and the proportion of individuals with moderate-to-severe infection were both higher in the dry season. We believe that the determining factor for the greater proportion of individuals with high parasite loads in the dry season is due to the nutrition provided to the animals during the month of July, in which there was a preponderance of sheep with a BCS of 2.

Nutrition is a key factor ensuring satisfactory health status in farm animals. The immune system is totally dependent on adequate amounts of nutrients, such as proteins, calories, vitamins, and minerals, in order to perform its protective function against possible pathogens in the body (Houdijk, 2012; Louvandini et al., 2015). Animals with poor nutritional status draw on their body reserve as a source of the energy and amino acids needed for survival (Houdijk et al., 2001). Consequently, when the body reserve is mobilized, the BCS tends to decrease, and, in chronic conditions of nutritional deficit, the immune system can be compromised and the susceptibility to helminth infections can increase (Louvandini et al., 2006).

Given the large interval of days without precipitation that preceded the months of July 2018 and July 2019-52 days and 37 days, respectively (INMET, 2018, 2019)-the climatic conditions during those two evaluation periods, especially the first of the two, were unfavorable to the satisfactory development of pastures, and, consequently, the forage available to the animals did not satisfy their nutritional demands, resulting in an increase in the proportion of lean animals. It is noteworthy that all of the farms evaluated provided some source of roughage during the dry season (hay, cane, or corn silage). However, given the observed proportions of individuals with a low BCS in dry periods, we can conclude that the supplementation offered did not satisfy the nutritional demands of the flocks. Despite the absence of precipitation in those periods, the relative humidity remained around 50\% (INMET, 2018, 2019), which allowed a considerable portion of the infective larvae to survive in the environment and, consequently, 
the infection to persist in the affected animals. In addition to the possible persistence of infectivity, the greater proportion of individuals with high parasite loads in the dry season might have been attributable to the unfavorable nutritional conditions.

As previously mentioned, 490 (34.15\%) of the 1435 sheep evaluated had moderate-to-severe parasitic infection. Due to their negative binomial distribution, gastrointestinal parasites present low quantities in most animals, although a small fraction of the flock can have a high parasite load (Louvandini et al., 2015). As observed in the present study, only $28.6 \%$ of the properties perform anthelmintic treatment of animals based on a selective criteria. In addition to treatment en masse, considering the administration of anthelmintics in animals with low parasitic loads, a significative problem observed was the dosage treatment based in visual appraisal of animal weight in the large majority of the properties evaluated, what seriously will impact the occurrence of anthelmintic resistance in the herds. That underscores the need for targeted, selective treatment of flocks, focused only on those individuals who in fact need therapeutic intervention for the control of parasitism. By adopting this management practice, the producer guarantees a reduction in costs related to anthelmintic treatments, the maintenance in refuge of a drug-sensitive nematode population, and lower selection pressure on helminths, thus preventing the emergence of anthelmintic resistance (Sargison, 2011).

In the present study, we found that the proportion of individuals with moderate-to-severe parasitic infection was lowest among sheep of the Santa Inês breed. As a national breed, highly adapted to the environmental conditions in Brazil, the Santa Inês breed is genetically more resistant to infection with gastrointestinal parasites. Various studies have reported that phenomenon (Bueno et al., 2002; Rocha et al., 2005, 2011).

We found that weaned lambs and lactating lambing ewes require greater attention, regarding the monitoring of gastrointestinal parasites, than do solitary ewes. It is estimated that in lambing ewes, especially during periparturition, that susceptibility is due to the interaction between several factors, such as hormonal oscillation, nutritional deficits, and high dietary demands (Amarante et al., 2015; Rocha et al., 2005, 2011). Because of the progressive development of the immune response, the younger an animal is, the more susceptible it will be to parasitism (Rocha et al., 2005). In the present study, the proportion of animals with a high parasite load was significantly greater in the weaned lamb category than in the other production categories, highlighting the need for weaned lambs to receive special attention in terms of health care.

From the logistic regression model applied in our study, it was possible to elucidate the multiple relationships among the phenotypic markers studied, in the environmental conditions of the cerrado biome. Considering that most of the evaluated properties carried out en masse treatment of their herds, without using EPG as a method of selecting sheep to be dewormed, the identification of phenotypic markers indicative of greater parasitic load in the herds of the Federal District of Brazil is an important measure to help control the disease.

Anemic animals presented higher parasite loads (higher proportions of individuals with moderate-to-severe infection), when compared with animals in which the hematocrit was within the reference range for the species. Given the predominance of helminth infection with Haemonchus spp. in the animals evaluated in the present study, together with the hematophagous nature of that nematode, acceptable levels of hematocrit are likely to correlate with a low parasite load. Jimenez-Sanz et al. (2016), as weel as Rosalinski-Moraes et al. (2012), observed negative correlate between hematocrit and OPG (-0.40 and -0.69 , respectively), demonstrating that, regarding conditions in which the Haemonchus genus predominate in helminth infections, hematocrit is a good diagnostic parameter in clinically sick animals. In dry season, when the proportions of individuals with EPG $\geq 800$ were higher, we also observed higher proportions of anemic sheep.

Anemia is also intrinsically related to the individual condition of resistance or resilience to haemonchosis (Amarante et al. 2004). In the Santa Ines breed, just as we observed lower proportions of individuals with moderate to severe infection, a small number of anemic sheep was also identified, showing the helminth genetic resistance of the breed. Among Dorper animals, despite a greater proportion of sheep with EPG $\geq 800$, a small fraction of individuals had hematocrit lower than $24 \%$, inferring a condition of resilience in such animals.

Sheep with loose or diarrheic feces showed higher parasite loads. Diarrhea is typically seen in animals with mixed parasitic infections, as was observed in the present study. Among the genera that trigger changes in the consistency of feces, Trichostrongylus and Oesophagostomum stand out due to their high frequency in sheep production systems (Amarante \& Sales, 2007; Amarante, 2015; Zajac, 2006). The diarrhea triggered by such agents is generally linked to lesions of the intestinal mucosa, with exudations and a loss of absorptive capacity (Amarante, 2015).

In the present study, a lean body was significantly associated with moderate-to-severe parasitic infection in sheep. Because gastrointestinal parasitism is the principal cause of weight loss in sheep (Vieira, 2008), low parasite loads 
reflect satisfactory body conditions. In addition, the BCS has been shown to correlate positively with hematocrit and negatively with EPG (Abrão et al., 2010; Quirino et al., 2011). Maintaining satisfactory nutritional conditions is an essential measure for the prevention of helminth infection. The greater probability of a high parasite load in the dry season underscores the need to monitor the nutritional status of the animals during such periods, in order to minimize the parasitic challenge during drought.

We found that sheep of breeds other than Santa Inês were more susceptible to helminth infections under the conditions evaluated in the present study. That is attributable to the fact that the Santa Inês breed has been genetically adapted to be less susceptible to parasitism. Rodrigues (2016) estimated that the heritability for the characteristic "resistance to helminth infection" is 0.85 in the breed.

Among the four periods evaluated in the present study, the genera of helminths observed appear to have been well adapted to the climatic conditions, which included average monthly rainfall ranging from $0 \mathrm{~mm}$ to $250 \mathrm{~mm}$, average monthly relative humidity ranging from $52 \%$ to $80 \%$, average monthly minimum temperatures ranging from $11.0^{\circ} \mathrm{C}$ to $18.5^{\circ} \mathrm{C}$, and monthly maximum temperatures ranging from $24.5^{\circ} \mathrm{C}$ to $28.0^{\circ} \mathrm{C}$. Despite the wide range of climatic conditions and the marked differences between the rainy and dry seasons, in terms of precipitation and relative air humidity, we observed similar proportional distributions of the helminth genera parasitizing the animals in both seasons. The optimal conditions for the development and transmission of Haemonchus spp. are reported to be monthly rainfall of $50 \mathrm{~mm}$ and an average monthly temperature above $17.7^{\circ} \mathrm{C}$ (Gordon, 1948) or between $15.0^{\circ} \mathrm{C}$ and $37.0^{\circ} \mathrm{C}$ (Levine et al., 1974). Because it is considered more resistant, the genus Trichostrongylus is thought to develop well in environmental conditions of low temperature and monthly precipitation between $5 \mathrm{~mm}$ and $10 \mathrm{~mm}$ (Reinecke, 1970; Ramos et al., 2004).

The higher proportions of parasites of the genus Haemonchus during the rainy season was an expected finding in the animals evaluated, because of the high fecundity and prolificacy of those parasites, as well as because the ecological conditions during the rainy season are ideal for their development and consequent infection of sheep. However, even during the dry season, the proportional distributions of the helminth genera, especially that of the predominant genus (Haemonchus), remained practically identical to those observed during the rainy season, a condition that is probably specific to the cerrado biome. Such observations contrast with the findings of Ramos et al. (2004), who evaluated sheep in the Brazilian state of Santa Catarina and found Haemonchus to be the predominant genus from late spring to summer, a period during which the average monthly rainfall is above $50 \mathrm{~mm}$, and the genus Trichostrongylus to be the predominant genus from autumn to late winter, a period during which temperatures are low. In a study conducted in the state of São Paulo, Fernandes et al. (2004) stated that, even during the so-called "dry season", the occurrence of light rains and an average relative humidity above 50\% allow the transmission of larvae from pasture lands. In inhospitable climatic conditions, the humid soil around water troughs, which are constantly visited by the animals, is also a possible source of helminth larvae persistence and consequent infection of sheep (Amarante et al., 2015).

The predominance of the genus Haemonchus observed in the present study is in keeping with the findings of other studies conducted in various regions of Brazil (Melo et al., 2009; Ramos et al., 2002; Rosalinski-Moraes et al., 2007; Sczesny-Moraes et al., 2010; Veríssimo et al., 2012). Because Haemonchus is the most prevalent, pathogenic, and infectious helminth genus among sheep in Brazil and is a hematophagous parasite, causing blood loss of up to $0.08 \mathrm{~mL}$ per day in a single individual, moderate-to-severe infections can generate large health and economic losses for sheep farming systems (Amarante et al., 2015). In the central-west region of Brazil, Sczesny-Moraes et al. (2010) and Silva et al. (2010) also observed predominance of the genera Haemonchus and Trichostrongylus among sheep flocks in the states of Mato Grosso do Sul and Mato Grosso, respectively. In a retrospective evaluation of necropsies of sheep and goats performed between 2003 and 2006 in the Federal District of Brazil (post mortem evaluations), Ataíde \& Cansi (2013) found that the most common agents of helminth infection were Haemonchus contortus and Oesophagostomum sp.

On the basis of the results obtained in the present study, we can conclude that, in the bioclimatic conditions of the Brazilian cerrado, as represented here by the Federal District of Brazil, heavy helminthic infections predominated in the dry season, especially in the weaned lamb and lactating lambing ewe production categories. In view of the predominance of the genus Haemonchus in the flocks evaluated, together with the similar distributions of helminth genera in the dry and rainy seasons, appropriate nutrition is essential to maintaining an appropriate immunological status and, consequently, to preventing and reducing the incidence of helminth infections. Changes in health management, with regard to helminth infection control, mainly regarding the adoption of selective anthelminthic treatment criteria for herds, are urgently needed in order to combat the disease more effectively and sustainably. 


\section{References}

Abrão DC, Abrão S, Viana CHC, Valle CR. Utilização do método Famacha no diagnóstico clínico individual de haemoncose em ovinos no Sudoeste do Estado de Minas Gerais. Rev Bras Parasitol Vet 2010; 19(1): 68-70. http://dx.doi.org/10.1590/S198429612010000100014. PMid:20385064.

Amarante AFT, Bricarello PA, Rocha RA, Gennari SM. Resistance of Santa Ines, Suffolk and Ile de France sheep to naturally acquired gastrointestinal nematode infections. Vet Parasito/ 2004; 120(1-2): 91-106. http://dx.doi.org/10.1016/j.vetpar.2003.12.004 PMid:15019147.

Amarante AFT, Sales RO. Controle de endoparasitoses dos ovinos: uma revisão. Rev Bras Hig Sanid Anim 2007; 1(2): 14-36. http:// dx.doi.org/10.5935/1981-2965.20070007.

Amarante AFT, Silva BF, Ragozo AMA. Os parasitas de ovinos. São Paulo: Unesp Digital; 2015. https://doi.org/10.7476/9788568334423.

Amarante AFT. Importância da resposta imunológica na profilaxia da verminose Ovina. In: Costa LM Jr \& Amarante AFT, editors. Controle de helmintos de ruminantes no Brasil. Jundiaí: Paco Editorial; 2015. p. 203-234.

Ataíde HS, Cansi ER. Ocorrência das doenças parasitárias em ovinos e caprinos no Distrito Federal, Brasil, durante 2003 a 2009. Arq Inst Biol 2013; 80(3): 342-345. http://dx.doi.org/10.1590/S1808-16572013000300012.

Barros JR. A chuva no Distrito Federal: o regime e as excepcionalidades do ritmo [dissertação] Rio Claro: Universidade Estadual Paulista; 2003.

Bueno MS, Cunha EA, Veríssimo CJ, Santos LE, Lara MAC, Oliveira SM, et al. Infección por nematodos en razas de ovejas cárnicas criadas intensivamente en la región del sudeste del Brasil. Arch Zootec 2002; 51(193-194): 271-278.

Cardia DFF, Rocha-Oliveira RA, Tsunemi MH, Amarante AFT. Immune response and performance of growing Santa Ines lambs to artificial Trichostrongylus colubriformis infections. Vet Parasitol 2011; 182(2-4): 248-258. http://dx.doi.org/10.1016/j. vetpar.2011.05.017. PMid:21641720.

Carneiro RD, Amarante AFT. Seasonal effect of three pasture plants species on the free-living stages of Haemonchus contortus. Arq Bras Med Vet Zootec 2008; 60(4): 864-872. http://dx.doi.org/10.1590/S0102-09352008000400014.

Centro de Previsão do Tempo e Estudos Climáticos - CPTEC. Dados climáticos, monitoramento Brasil mensal [online]. Brasília; 2019 [cited 2019 Jan 1]. Available from: http://clima1.cptec.inpe.br/monitoramentobrasil/pt

Chagas ACS, Niciura SCM, Molento MB. Manual prático: metodologia de diagnóstico da resistência e de detecção de substâncias ativas em parasitos de ruminantes. Brasília: EMBRAPA; 2011.

Charles TP. Disponibilidade de larvas infectantes de nematódeos gastrintestinais parasitas de ovinos deslanados no semi-árido pernambucano. Cienc Rural 1995; 25(3): 437-442. http://dx.doi.org/10.1590/S0103-84781995000300019.

Climatempo. Climatologia [online]. Brasília; 2020 [cited 2020 Oct 6]. Available from: https://www.climatempo.com.br/ climatologia/61/brasilia-df

Costa RLD, Bueno MS, Veríssimo CJ, Cunha EA, Santos LE, Oliveira SM, et al. Performance and nematode infection of ewe lambs on intensive rotational grazing with two different cultivars of Panicum maximum. Trop Anim Health Prod 2007; 39(4): 255-263. http://dx.doi.org/10.1007/s11250-007-9005-5. PMid:17847820.

Costa VMM, Simões SVD, Riet-Correa F. Controle das parasitoses gastrintestinais em ovinos e caprinos na região semiárida do nordeste do Brasil. Pesq Vet Bras 2011; 31(1): 65-71. http://dx.doi.org/10.1590/S0100-736X2011000100010.

Empresa Brasileira de Pesquisa Agropecuária - EMBRAPA. Evolução anual do efetivo de rebanho de ovinos (cabeças): mundo [online]. Brasília; 2019 [cited 2019 Oct 17]. Available from: https://www.embrapa.br/en/cim-inteligencia-e-mercado-de-caprinose-ovinos/producao-mundial

Fernandes LH, Seno MCZ, Amarante AFT, Souza H, Belluzzo CEC. Efeito do pastejo rotacionado e alternado com bovinos adultos no controle da verminose em ovelhas. Arq Bras Med Vet Zootec 2004; 56(6): 733-740. http://dx.doi.org/10.1590/S010209352004000600006

Food and Agriculture Organizations - FAO. Biological control of gastro-intestinal nematodes of ruminants using predacious fungi. Rome: FAO; 1998. (FAO Animal Production and Health Papers).

Girão ES, Girão RN, Medeiros LP. Verminose em ovinos e seu controle. Teresina: Embrapa Meio-Norte; 1998.

Gordon HML. The epidemiology of parasitic diseases, with special reference to studies with nematode parasite of sheep. Aust Vet J 1948; 24(2): 17-45. http://dx.doi.org/10.1111/j.1751-0813.1948.tb01569.x.

Hansen J, Perry B. The epidemiology, diagnosis and control of helminth parasites of ruminants. Nairobe: ILRAD-FAO; 1994.

Hassum IC. Instruções para coleta e envio de material para exame parasitológico de fezes - OPG e coprocultura para ruminantes. Bagé: Embrapa Pecuária Sul; 2008. 
Houdijk JGM, Jessop NS, Kyriazakis I. Nutrient partitioning between reproductive and immune functions in animals. Proc Nutr Soc 2001; 60(4): 515-525. http://dx.doi.org/10.1079/PNS2001114. PMid:12069405.

Houdijk JGM. Differential effects of protein and energy scarcity on resistance to nematode parasites. Small Rumin Res 2012; 103(1): 41-49. http://dx.doi.org/10.1016/j.smallrumres.2011.10.017.

Igarashi M, Carvalho DMG, Bucci FC, Miranda Y, Rodrigues ZM, Almeida MCF, et al. Efeito do neem (Azadirachta Indica) no controle de nematódeos gastrintestinais em ovinos suplementados a pasto no período seco. Semina: Ciênc Agrár 2013; 34(1): 301-310. http://dx.doi.org/10.5433/1679-0359.2013v34n1p301.

Instituto Brasileiro de Geografia e Estatística - IBGE. Pesquisa agropecuária municipal: ano 2018 [online]. 2018 [cited 2019 Oct 17]. Available from: https://sidra.ibge.gov.br/tabela/3939\#resultado

Instituto Nacional de Meteorologia - INMET. Boletim Agroclimatológico mensal de dezembro de 2017 [online]. 2017 [cited 2018 Oct 31]. Available from: http://www.inmet.gov.br/portal/arq/upload/BOLETIM-AGRO_MENSAL_201712.pdf

Instituto Nacional de Meteorologia - INMET. Boletim Agroclimatológico mensal de julho de 2018 [online]. 2018 [cited 2018 Oct 31 ]. Available from: http://www.inmet.gov.br/portal/arq/upload/BOLETIM_AGRO_MENSAL_201807.pdf

Instituto Nacional de Meteorologia - INMET. Estações automáticas: gráficos [online]. 2019 [cited 2019 Oct 17]. Available from: http://www.inmet.gov.br/portal/index.php?r = home/page\&page = rede_estacoes_auto_graf

Jimenez-Sanz AL, Quirino CR, Pacheco A, Costa RLD, Beltrame RT, Rua MAS, et al. Relação entre fatores associados às parasitoses gastrointestinais, desempenho e estado fisiológico de ovelhas Santa Inês. Agropec Tec 2016; 37(1): 88-95. http://dx.doi. org/10.25066/agrotec.v37i1.25170.

Levine ND, Todd KSJ Jr, Boatman PA. Development and survival of Haemonchus contortus on pasture. Am J Vet Res 1974; 35(11): 1413-1422. PMid:4473945.

Lopes STA, Biondo AW, Santos AP. Manual de patologia clínica veterinária. 3. ed. Santa Maria: UFSM/Departamento de Clínica de Pequenos Animais; 2007.

Louvandini H, Canova EB, Campos FC, Abdalla AL, McManus CM, Katitki LM, et al. A importância da nutrição na resiliência dos ruminantes às verminoses. In: Costa LM Jr \& Amarante AFT, editors. Controle de helmintos de ruminantes no Brasil. Jundiaí: Paco Editorial; 2015. p. 185-202.

Louvandini H, Veloso CFM, Paludo GR, Dell'Porto A, Gennari SM, McManus CM. Influence of protein supplementation on the resistance and resilience on Young hair sheep naturally infected with gastrointestinal nematodes during rainy and dry season. Vet Parasito/ 2006; 137(1-2): 103-111. http://dx.doi.org/10.1016/j.vetpar.2006.01.004. PMid:16495016.

Martins EC, Magalhães KA, Souza JDF, Guimarães VP, Barbosa CMP, Holanda ZF Fo. Cenário mundial e nacional da ovinocultura e da caprinocultura - ativos ovinos e caprinos [online]. Brasília: Embrapa Caprinos e Ovinos; 2016 [cited 2018 Apr 1]. Avaliable from: https://www.embrapa.br/documents/1355090/0/Ativo_Ovinos_Caprinos/2cba6db9-b704-4183-ba43-a8214b28eaa4?version = 1.0

Melo ACFL, Bevilaqua CML, Reis IF. Resistência aos anti-helmínticos benzimidazóis em nematóides gastrintestinais de pequenos ruminantes do semiárido nordestino brasileiro. Cienc Anim Bras 2009; 10(1): 294-300.

Quirino CR, Carneiro-Silva RM, Costa RID, Madella-Oliveira AF. Correlações entre peso, escore de condição corporal, famacha, volume globular e ovos por grama de fezes em ovelhas Santa Inês. Actas Iberoameric Conserv Anim 2011; 1(1): 319-322.

Ramos Cl, Bellato V, Ávila VS, Coutinho GC, Souza AS. Resistência de parasitos gastrintestinais de ovinos a alguns anti-helmínticos no estado de Santa Catarina, Brasil. Cienc Rural 2002; 32(3): 473-477. http://dx.doi.org/10.1590/S0103-84782002000300017.

Ramos Cl, Bellato V, Souza AP, Avila VS, Coutinho GC, Dalagnol CA. Epidemiologia das helmintoses gastrintestinais de ovinos no Planalto Catarinense. Cienc Rural 2004; 34(6): 1889-1895. http://dx.doi.org/10.1590/S0103-84782004000600034.

Reinecke RKA. Helminth diseases in domestic animals in relation to their environment. S Afr J Sci 1970; 66(6): $192-198$.

Rocha RA, Amarante AFT, Bricarello PA. Resistance of Santa Inês and lle de France suckling lambs to gastrointestinal nematode infections. Rev Bras Parasitol Vet 2005; 14(1): 17-20. PMid:16153339.

Rocha RA, Bricarello PA, Silva MB, Houdijk JGM, Almeida FA, Cardia DFF, et al. Influence of protein supplementation during late pregnancy and lactation on the resistance of Santa Ines and Ile de France Ewes to Haemonchus contortus. Vet Parasitol 2011; 181(2-4): 229-238. http://dx.doi.org/10.1016/j.vetpar.2011.03.055. PMid:21726941.

Rodrigues FN. Genética da resistência à verminose em ovinos Santa Inês [dissertação]. Teresina: Universidade Federal do Piauí; 2016.

Rosalinski-Moraes F, Fernandes FG, Munaretto A, Oliveira S, Wilmsen MO, Pereira MW, et al. Método FAMACHA@, escore corporal e de diarreia como indicadores de tratamento anti-helmíntico seletivo de ovelhas em reprodução. BiosciJ 2012; 28(6): 1015-1023.

Rosalinski-Moraes F, Moretto LH, Bresolin WS, Gabrielli I, Kafer L, Zanchet IK, et al. Resistência Anti-helmíntica em rebanhos ovinos da região da associação dos municípios do Alto Irani (AMAI), oeste de Santa Catarina. Cienc Anim Bras 2007; 8(3): 559-566. 
Santos MC, Silva BF, Amarante AFT. Environmental factors influencing the transmission of Haemonchus contortus. Vet Parasitol 2012; 188(3-4): 277-284. http://dx.doi.org/10.1016/j.vetpar.2012.03.056. PMid:22521972.

Sargison ND. Pharmaceutical control of endoparasitic helminth infection in sheep. Vet Clin North Am Food Anim Pract 2011; 27(1): 139-156. http://dx.doi.org/10.1016/j.cvfa.2010.10.014. PMid:21215898.

Sczesny-Moraes EA, Bianchin I, Silva KF, Catto JB, Honer MR, Paiva F. Resistência anti-helmíntica de nematóides gastrintestinais em ovinos, Mato Grosso do Sul. Pesq Vet Bras 2010; 30(3): 229-236. http://dx.doi.org/10.1590/S0100-736X2010000300007.

Silva MRL, Souza EA, Bonelli EA, Medeiros MO, Silva GF, Queiroz EO. Parasitas gastrintestinais de ovinos criados na região de Rondonópolis - MT. Biodiversidade 2010; 9(1): 67-73.

Sorio A, Magalhães LA, Marques WA. Carne ovina: o ontem, o hoje e o amanhã. Brasília: Escola Superior do Agronegócio; 2016.

Statacorp. Stata: release 12: statistical software. College Station, TX: StataCorp LP; 2011.

Thompson JM, Meyer H. Body condition scoring of sheep. Oregon State university Extension service [online] 1994. [cited 2017 Nov 18]. Available from: http://ir.library.oregonstate.edu/xmlui/bitstream/handle/1957/14303/ec1433.pdf;jsessionid = 8AA0EB192 164AB34811459DAB85E1762? sequence $=1$

Ueno H, Gonçalves PC. Manual para diagnóstico das helmintoses de ruminantes. 4. ed. Tóquio: Japan International Cooperation; 1998.

Van WykJA, Bath GF. The FAMACHA® system for managing haemonchosis in sheep and goats by clinically identifying individual animals for treatment. Vet Res 2002; 33(5): 509-529. http://dx.doi.org/10.1051/vetres:2002036. PMid:12387487.

Van WykJA, Cabaret J, Michael LM. Morphological identification of nematode larvae of small ruminants and cattle simplified. Vet Parasitol 2004; 119(4): 277-306. http://dx.doi.org/10.1016/j.vetpar.2003.11.012. PMid:15154594.

Vatta AF, Letty BA, Van Der Linde MJ, Van Wijk EF, Hansen JW, Krecek RC. Testing for clinical anaemia caused by Haemonchus spp. in goats farmed under resource-poor conditions in South Africa using an eye colour chart developed for sheep. Vet Parasitol 2001; 99(1): 1-14. http://dx.doi.org/10.1016/S0304-4017(01)00446-0. PMid:11445151.

Veríssimo CJ, Niciura SCM, Alberti ALL, Rodrigues CFC, Barbosa CMP, Chiebao DP, et al. Multidrug and multispecies resistance in sheep flocks from São Paulo state, Brazil. Vet Parasito/ 2012; 187(1-2): 209-216. http://dx.doi.org/10.1016/j.vetpar.2012.01.013. PMid:22341829.

Viana FAB. Guia terapêutico veterinário. 3. ed. Lagoa Santa: Editora Cem; 2014.

Vieira LS. Métodos alternativos de controle de nematoides gastrintestinais em caprinos e ovinos. Tecnol Cienc Agropec 2008; 2(2): 49-56.

Zajac AM. Gastrointestinal nematodes of small ruminants: life cycle, anthelmintics, and diagnosis. Vet Clin North Am Food Anim Pract 2006; 22(3): 529-541. http://dx.doi.org/10.1016/j.cvfa.2006.07.006. PMid:17071351. 